\title{
UMA INVESTIGAÇÃO SOB RE A IMPLEMENTAÇÃO DO IMPOSTO SOBRE GRANDES FORTUNAS NO BRASIL
}

\section{Leila Thainá Fontoura Bezerra; Cleiton Silva de Jesus}

Bolsista PROBIC/UEFS Graduanda em Economia, Universidade Estadual de Feira de Santana, e-mail: lele.fontoura@gmail.com

2. Orientador, Departamento de Ciências Sociais Aplicadas, Universidade Estadual de Feira de Santana, e-mail: cleiton.uefs@gmail.com

Palavras-chaves: imposto sobre Grandes Fortunas no Brasil; Justiça Fiscal; Justiça Social.

\section{INTRODUÇÃO:}

O imposto sobre Grandes Fortunas (IGF) é um imposto progressivo sobre o patrimônio/riqueza e está na Constituição Federal de 1988, artigo 153, inciso VII, instituído por FHC em 1989. Contudo, até os dias atuais não foi regulamentado. Diversos projetos de lei que objetivavam a regulamentação do mesmo foram apresentados no Congresso Nacional, porém as tentativas não foram exitosas. Acreditase que o principal entrave para a regulamentação do mesmo seja de natureza política.

A ideia de implantar o IGF no nosso ordenamento tributário advém de um sistema marcado por iniquidades, da percepção da falta de tributação específica para algumas riquezas acumuladas e não produtivas, além deste imposto ser um mecanismo que permita amenizar a dívida pública. Tal ideia foi também fortemente influenciada pela experiência francesa, que em 1982 adotou o "Impôt sur les Grandes Fortunes', e posteriormente em 1988, Impôt Solidarité sur la Fortune (ISF) pelo governo socialista. Conforme o estudo de Carvalho (2011), a França obteve uma taxação satisfatória: o número de contribuintes cresceu de 168 mil para 562 mil famílias no período de 19922010. Perfazendo assim, num montante de cerca de 4,5 bilhões em 2010.

Mota (2010) acredita que a regulamentação do imposto sobre Grandes Fortunas, teoricamente viabilizaria amenizar a acentuada desigualdade social, uma vez que o IGF tem a capacidade de ser um dispositivo de promoção de justiça tributária e, de especial interesse para a política fiscal a fim de repartir as rendas e as riquezas.

O imposto sobre Grandes Fortunas no Brasil (IGF) pode trazer impactos positivos no nosso ordenamento fiscal e social. Esta taxação, em tese, visa corrigir as injustiças 
advindas da obtenção e do acúmulo de riquezas, combatendo a pobreza, amenizando as desigualdades sociais, distribuindo rendas e riquezas e, sobretudo contribui para uma prática tributária mais justa, equânime, em concordância ao princípio da capacidade tributária.

Segundo estimativas da Receita Federal (2016), 2,5 milhões de famílias da classe A detém 37,4 da massa de renda nacional. A renda das famílias da classe A é 40,9 vezes maior do que as classes D/E. Outro estudo da Receita Federal (2015) indica o Brasil está em décimo lugar no mundo a respeito do problema da desigualdade de renda. Há ainda outro problema inserido diante desta problemática: o incentivo à formação de super-ricos.

Assim, o IGF insere-se dentro desta problemática e a ideia de implantá-lo no no nosso ordenamento tributário advém de um sistema marcado por iniquidades, da concentração de riqueza e renda, da percepção da falta de tributação específica para algumas riquezas acumuladas e não produtivas, além deste imposto ser um mecanismo que permita amenizar a dívida pública. Disto, para a política fiscal pode favorecer uma arrecadação e distribuição maior de renda.

A literatura econômica internacional ressalta que Imposto recorrente sobre Riqueza Liquida, juntamente com os impostos sobre Herança e/ ou doações (ITCM), que estão inseridos no contexto da existência da riqueza/patrimônio pessoal, representa uma eficácia em termos distributivos ou mais desejáveis em nível de equidade, visto que a riqueza líquida é normalmente calculada sobre o valor líquido do patrimônio do contribuinte, ou seja, valor do bem deduzido de ônus e dívidas. (Carvalho 2011)

Há ainda uma justificativa moral, ao tributar pesadamente as heranças, já que os herdeiros não tiveram esforço para formar o patrimônio, e isso os incentivaria a investirem em educação própria e/ou atividades empreendedoras. Alguns defensores da corrente neoclássica também argumentam que os impostos sobre a propriedade não interferem no mercado de trabalho, ou seja, nas relações entre trabalho e lazer. Apesar de resultados fiscais insatisfatórios, espera-se que a tributação sobre heranças e sobre a riqueza líquida pelo menos previna uma concentração excessiva da renda.(CARVALHO 2011) 
No Brasil, embora apresente tributos progressivos sabe-se que o sistema de tributação no Brasil é marcado pela regressividade, ora paga mais quem ganha menos, implicando assim no fracasso da função distributiva que a ele se atribui como medida transformadora da realidade social. Isto decorre da representatividade elevada dos impostos indiretos (IPI, ICMS, ISS entre outros) sobre o total da carga tributária e de uma pouca efetividade dos impostos sobre o patrimônio e a renda. (SEVEGNANNI, 2012)

Com a regulamentação do IGF diminuiria esta forte regressividade deste sistema, descentralizaria mais recursos para o Estado e Municípios. É estimado que a incidência sobre o patrimônio/ riqueza, poderia resultar num montante equivalente a aproximadamente 100 bilhões de reais por ano se fosse aplicado em uma simulação hipotética, com alíquota média de $1 \%$, a respeito de valores superiores a um milhão de reais (KHAIR, 2015).

\section{MATERIAL E MÉTODOS}

Como nesta pesquisa procurou-se investigar a implementação do imposto sobre Grandes Fortunas no Brasil o principal método utilizado foi o indutivo. Além deste, a pesquisa teve cunho observacional, comparativo, explicativo, estatístico. Informações também foram advindas da Receita Federal para a análise de desigualdade social, bem como de nota técnica do Instituto de pesquisa econômica aplicada (IPEA). Neste trabalho também foi utilizado livros e artigos científicos, análise dos projetos de lei do Senado Federal, Câmara Governamental para dar suporte à pesquisa.

\section{ANÁLISE E DISCUSSÃO DOS RESULTADOS:}

Dada a regressividade tributária, bem como do grau de concentração de riqueza, o ajuste fiscal com o aumento da progressividade dos impostos; a maior representatividade dos impostos sobre herança; Um imposto de renda mais progressivo; Cobrança de lucros e dividendos dos empresários; Provar a eficiência administrativa e arrecadatória do IGF a fim de efetivá-lo no ordenamento tributário/fiscal brasileiro. 
Ademais, estas medidas conjuntamente podem para trazer mais fôlego a economia e consequentemente melhorar as contas públicas ao redistribuir a renda dos mais ricos para as classes mais pobres, fomentando ainda mais o consumo.

\section{CONSIDERAÇÕES FINAIS:}

O trabalho procurou investigar se a adoção do Imposto sobre Grandes Fortunas é factível. Contudo, até os dias atuais está meramente apenas no texto constitucional. O principal entrave para a não regulamentação do IGF é de natureza política, dado aos diversos projetos de Lei projetos de lei existentes, que em suas discussões esconde contradições e manipulações políticas. Disto conclui que este tipo de imposto, em sua própria razão de ser está inserido num contexto de prós e contras e não há ainda um consenso para a sua regulamentação.

Dado aos graves indicadores de desigualdade social ainda persistente no Brasil, investigar a implementação do IGF carrega um aspecto positivo, pois inevitavelmente traz à tona o nosso modelo tributário regressivo que onera as classes menos favorecidas, haja vista sua capacidade de ser um instrumento nas mãos do Estado para minimizar o drástico contexto de desigualdade.

Os possíveis caminhos devem estar centrados numa tributação mais justa e que distribua os recursos eficientemente.

\section{REFERÊNCIAS:}

ALVARENGA, Darlan. 71 mil brasileiros concentram $22 \%$ de toda riqueza. Disponível em: <http://g1.globo.com/economia/noticia/2015/08/71-mil-brasileirosconcentram-22-de-toda-riqueza-veja-dados-da-receita.html_.Último acesso em: $25 / 04 / 2016$

CARVALHO, Pedro Humberto Bruno de. As discussões sobre a regulamentação do Imposto sobre Grandes Fortunas: a situação no Brasil e a experiência internacional. Nota Técnica-IPEA. Publicado em: out. 2011. Disponível 
em:<http://www.ipea.gov.br/agencia/images/stories/PDFs/nota_tecnica/111230_notatec nicadinte7.pdf $>$.

CORSATTO, Olavo N. Imposto sobre grandes fortunas. Revista de Informação Legislativa, v. 37, n. 146,

abr./jun.2000.

GERBELLI, Luiz Guilherme. Classe A tem maior fatia de renda do país, Disponível em: $<$ http://economia.estadao.com.br/noticias/geral,classe-a-tem-maior-fatia-da-rendado-pais, 10000007285> Último acesso em: 25/04/2016

ONU NAÇÕES UNIDAS DO BRASIL. Brasil é paraíso tributário para super-ricos. Publicado em: 31/03/2016. Disponível em: https://nacoesunidas.org/brasil-e-paraisotributario-para-super-ricos-diz-estudo-de-centro-da-onu/

KHAIR, Amir. Imposto sobre Grandes Fortunas renderia 100 bilhões por ano

(2015) - $\quad$ Publicado em: 03/03/2015 Disponível em: $<$ http://www.cartacapital.com.br/economia/imposto-sobre-grandes-fortunas-renderia100-bilhoes-por-ano-1096.html>

SEVEGNANI, Joacir. (2012) O modelo regressivo de tributação no Brasil. 